\title{
Comparing Ottoman Municipalities in Palestine: The Cases of Nablus, Haifa, and Nazareth, 1864-1914
}

\author{
Mahmoud Yazbak
}

It has been suggested that the European presence in Ottoman cities and the subsequent pressure on the Ottoman administration led to the creation of Ottoman municipalities. This theory implies that local Muslim societies were stagnant and lacked the required resources for social and urban change. ${ }^{1}$ Based upon findings from three Palestinian Ottoman cities: Nablus, Haifa, and Nazareth, this chapter claims that urban services had been established long before the foundation of the municipalities or the presence of Europeans in Palestine. In this respect, the law regarding municipalities and their establishment was not a true innovation. When they were created, Ottoman municipalities took on public services that had been present many years before. However, at the local level, the institution of the municipality, which was part of the overall reform process, produced new systems of social and political change. ${ }^{2}$

Until the 1870s, the presence of Europeans in Haifa and Nazareth was too limited to exert serious pressure on the Ottoman authorities. Nablus was the main town in the mountainous region of central Palestine, and it served as a hub for the commerce, manufacturing, and administration of its hinterland. Culturally, Nablus remained largely unaffected by the rising commercial, cultural, and missionary ties that allowed Europe to penetrate into Palestine in the $1850 \mathrm{os}$. With a predominantly Muslim population of 20,000, the town was inhabited by just a few hundred Christians and Samaritans. Nablus remained largely stable; it was unaffected by immigration, and preserved its autonomous cultural identity long after the mid-nineteenth century. It had succeeded

1 For a thorough discussion of these theories see Mahmoud Yazbak, "The Municipality of a Muslim Town: Nablus, 1868-1914," Archiv Orientalni 67, no. 3 (1999): 339-341.

2 In this chapter, I do not discuss at length the urban services provided by the municipal council, a theme I deal with in "Municipality of a Muslim Town," 348-59. Among other aspects, that article discusses the municipal budget and municipal services such as town planning, sanitation and lighting, supervision of markets, police and security and other aspects of services.

(C) MAHMOUD YAZBAK, 2018 | DOI:10.1163/9789004375741_016

This is an open access chapter distributed under the terms of the prevailing CC-BY-NC-ND License at the time of publication. 
in maintaining autonomous rule to a large extent, and Nablus' elite resisted changes that could have altered its traditional social structures. ${ }^{3}$

Haifa was rebuilt in the 1750 s, and continued to develop until the 1830 s. It had a suitable anchorage for steamships, and it became the main port of northern Palestine and the Hawran. In 1905, when the Ottoman government made it one of the central stations of the Hijaz Railroad, Haifa's port became second in importance to Beirut. The population of Haifa grew from about two thousand in the mid-nineteenth century, to about twenty thousand at the turn of the century. Muslims made up half of the population; the rest was made up of Christians and other religious minorities. Since the town was too young to have a well-established traditional elite, it proved easier for new immigrant families in Haifa to become part of the elite than in older towns such as Nablus. ${ }^{4}$

Nazareth is located in a strategic point in the southern Galilee Mountains, overlooking the Esdraelon valley. It came to life in the 1750s, when it became a government base. Its prominent and powerful governor, Dahir al-'Umar, gave permission for four churches to be built in the town: Greek Orthodox, Roman Catholic, Maronite, and Latin. This encouraged general settlement in Nazareth and led to further regeneration in the area. Dahir's successors continued his policy, and its population grew to about four thousand in the 185 os, and to ten thousand in the 1880 s. $^{5}$ Since it was one of the holy places for Christianity, Nazareth began to attract many missionary societies during the second half of the nineteenth century. In less than fifty years, forty-four missionary establishments had been set up in the town. ${ }^{6}$ Muslims made up

3 Mahmoud Yazbak, "Nabulsi Ulama in the Late Ottoman Period, 1864-1914," International Journal of Middle East Studies 29, no. 1 (1997); Beshara B. Doumani, Rediscovering Palestine: Merchants and Peasants in Jabal Nablus, 1700-19oo (Berkeley: University of California Press, 1995), 9, 23, 68, 73-74, 107. Cf. also Butrus Abu-Manneh, "The Islamic Roots of the Gulhane Rescript," Die Welt des Islams 34, no. 2 (1994).

4 For a thorough study of Ottoman Haifa, see Mahmoud Yazbak, Haifa in the Late Ottoman Period, 1864-1914: A Muslim Town in Transition (Leiden: Brill, 1998); Muhammad Rafiq (al-Tamimi) and Muhammad Bahjat, Wilayat Bayrut [Province of Beirut], 3rd ed., 2 vols. (Beirut: Dar Lahd Khatir, 1987), vol. 1, 387-89.

5 Mahmoud Yazbak, "Europe, Cotton and the Emergence of Nazareth in 18th-Century Palestine," Oriente Moderno 93, no. 2 (2013).

6 Tamimi and Rafiq, Wilayat Bayrut, 378, 383; As‘ad Mansur, Tarikh al-Nasira min Aqdam Azmaniha Ila Ayamina al-Hadira [History of Nazareth from early times to our days] (Cairo, 1924), 124; Chad Fife Emmett, "The Christian and Muslim Communities and Quarters of the Arab City of Nazareth" (PhD diss., University of Chicago, 1991), 51. 
one-third of the town's population, and the remainder were Christians of different denominations. ${ }^{7}$

However, two forces of change emerged in the middle of the nineteenth century, affecting the nature of society in Palestine. Istanbul began implementing direct rule and sought to put an end to autonomous local forces. Meanwhile, Europe moved in to undermine the traditional local economic relations and push society towards capitalization. Naturally, these trends affected the empire as a whole, but were felt particularly in Palestine. In Nazareth and Haifa, where the European presence became larger and Christian communities more dominant, these effects were felt more strongly than in Nablus.

\section{The Sources}

Nablus' local archives, the Ottoman and British Mandate municipal archives, as well as private family papers, are much richer than documents from Nazareth and Haifa. This is mainly because Nablus was not significantly affected by the Palestinian Nakba in 1948, and its local institutions were not destroyed or burned in wartime. The people of Nablus were not expelled from their homes as families were in Haifa and other Palestinian cities that became part of the Israeli state after 1948 were. Therefore, collections of documents can still be found intact in the houses of members of the old elite who served in administrative positions. ${ }^{8}$ The local archives of Nablus contain an almost complete series of the sharia court's sijillät from the sixteenth century until the end of Ottoman rule. Many of these archival collections have been photocopied by a team at al-Najah University in Nablus, and are kept at the university's Center of Advanced Studies. A copy of them is also kept at the Jordanian University in Amman as part of the Bilad al-Sham Studies Centre archives.

Nablus' municipal archives from the Ottoman period contain eighty volumes of the municipal council's protocols, which are divided into a collection of two volumes of the local elections to the municipal council (the

7 Justin McCarthy, The Population of Palestine: Population History and Statistics of the late Ottoman Period and the Mandate (New York: Columbia University Press, 1990), 59; Titus Tobler, Nazareth in Palästina (Berlin: Reimer, 1868), 65-68.

8 See for example, Mahmoud Atallah, Fahras Makhtutat Al-Tuffaha [An index of manuscripts of the Tuffaha family] (Nablus, 1993); see also the manuscripts of the Al-Jaqqah family, kept in the library of al-Najah University in Nablus. 
administrative council and the Ottoman parliament), a large collection of forty-five volumes related to municipality budgets, incomes and expenditures, seventeen volumes containing the municipality's council decisions and minutes, and sixteen volumes on miscellaneous topics (see tables 12.1-4).

Original volumes of the above collections are kept at the municipal archives of the city of Nablus, located in the municipal library in the Shwitra neighborhood. These collections were filmed by Al-Najah University of Nablus, and are stored on $16 \mathrm{~mm}$ microfilms at the Documentation, Manuscripts and Publication Centre of the university, a division of the university's general library. Similar microfilmed copies are also held at the Jordanian University in Amman, in the Bilad al-Sham Studies Centre archives. The microfilmed copies of the municipal archival collections of Nablus are available upon request, and include four microfilms corresponding to about four thousand A4 pages. The first microfilm was labeled arbitrarily by Al-Najah University librarians as the "first collection" (al-Majmu'a al-Ula) and comprises sixteen volumes. The collection is made up of detailed registers or daftars (Ott. Turk. s. defter) of daily incomes and expenditures of the municipality of Nablus (Daftar Yawmiyyat wa Waridat wa Musarafat Baladiyyat Nablus). ${ }^{9}$ The expenditures includes detailed lists of salaries and payments paid to all employees of the municipality. At the end of each day, all items of expenditures and incomes were calculated and signed by the municipal scribe (kätib) and the treasurer (amin sunduq). At the end of each month, all expenditures and incomes of the municipal treasury were calculated, signed, and sealed by the mayor, the treasurer, the municipal scribe, and members of the municipal council. At the end of each financial year, similar annual calculations were made and signed by the mayor and council members.

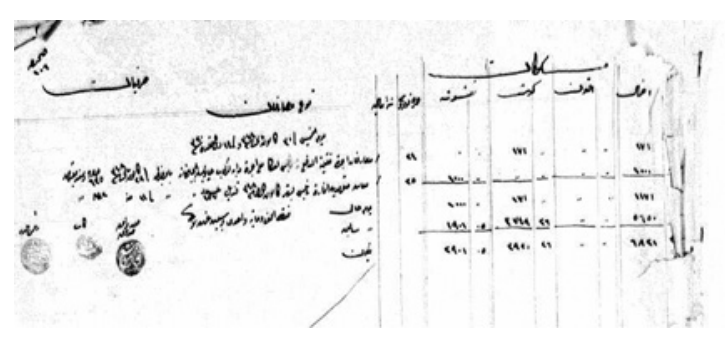

FIGURE 12.1 Municipal Archives of Nablus, expenditures document, first collection, vol. 1, 106.

9 Municipal Archives of Nablus (MAN), div. 1. 


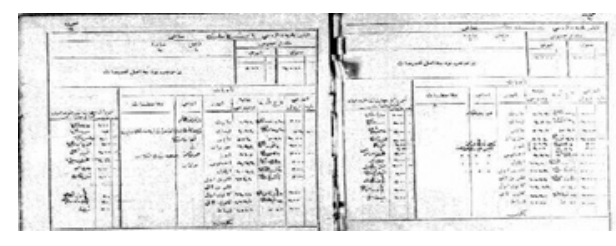

FIGURE 12.2

Municipal Archives of Nablus, document of printed headers, first collection, vol. 3,3 .

The volumes of the first collection are legible and remain in good condition. Some are written in Arabic and others in Ottoman (see table 12.1). The scribe wrote with a clear hand and the pages are generally well organized. However, the pages of certain daftars are missing. The first daftar, for example, begins on page 92 and ends on page 107. Most of the other daftars of the first collection are complete and each volume contains around seventy pages. The third volume of this collection includes more notes in Ottoman Turkish than the previous two volumes. From the third volume (1903) on, the scribe stopped using dual calendars, that is, Rumi (fiscal) and the Hijri. In 1903, Istanbul began to supply the municipalities with daftars that included printed headers and tables in the Ottoman language. These headers and tables showed all of the information that was to be filled in by the scribes (fig. 12.2), who abided only by the fiscal calendar. Our documents do not include any official order concerning the shift from dual calendars to the fiscal calendar, but it is safe to say that it may have reflected the increasing Turkish influence coming from Istanbul.

A new format of these daftars appeared with the fourth volume. While the previous three volumes included the daily activities of the financial department of the municipality, the fourth volume included just one detailed registration of the income of the municipal treasury. Almost all the details of the monthly registers were written in Ottoman Turkish and were examined by an inspector representing the wilayya (province). The inspector visited the municipality from time to time. It seems that the daftars were written in Turkish to facilitate the job of the inspectors, who did not read Arabic. Volume 6 shows that at the end of December 1906, the inspector paid a visit to the municipality of Nablus. He inspected all incomes, expenditures, and accounts, and reported them to the wāli. ${ }^{10}$ The last pages of daftars 11-14 included a synopsis of expenditures and incomes and calculations of the annual municipal budget. It seems that this new regulation was intended to keep a closer eye on expenditures, and to make sure that the municipal treasury ended the fiscal year with a positive net budget. 


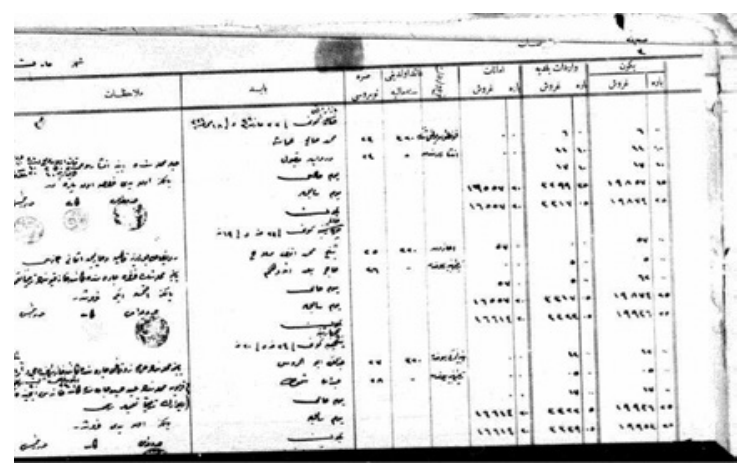

FIGURE 12.3

Municipal Archives of Nablus,

first collection, vol. 1, 3 .

An innovation called daftar shatib began to appear from volume 16 onwards. The daftar shatib was a draft register, or a document detailing fixed and anticipated expenditures. Each page of this daftar was dedicated to a separate source of expenditures. For example, each employee had a dedicated page where all payments paid to him throughout the year were registered (fig. 12.3).

For a reason that remains unclear, the municipal archivists decided to create a second collection of municipal volumes. All volumes of this new collection are related to the municipal budget and are labeled collectively as "ijmāli (summary or total) incomes of Nablus Municipality for the year." Each page of these volumes contains a summarized list of the total monthly income of the municipal treasury. Each volume is approximately 20 to 30 pages long. I have included the first and second collections in table 12.1 because they are related to the budget. I have also mentioned their titles and the time periods to which they relate.

The first two registers in table 12.1 are entitled ijmāli incomes (wäridat) of the municipality of liwa (district of) al-Balqa for the years 1292 Maliye (fiscal year) (M) (1876) until $1298 \mathrm{M}$. (December 1882). When the municipality of Nablus was established, it included in its jurisdiction not only the city of Nablus itself, but also all the towns of the liwa. From mid-1882, the jurisdiction of the municipality of Nablus was limited to the city of Nablus itself. Examining the contents of these two volumes reveals that each volume was divided into monthly records, and each record included a detailed registration of every item. At the end of each month, the municipal registrar calculated the incomes and the document was signed by members of the municipal council and the mayor. Before 1882, the mayor was referred to as the "mayor of the liwa of al-Balqa." In mid-December 1882, he became the mayor of Nablus. 
TABLE 12.1 Inventory of the daftars of the budget: Income and expenditure of the Municipality of Nablus (first and second collections)

Coll. Vol. Title of daftar

Fiscal year

Pages

Notes

Maliye AD (March-February)

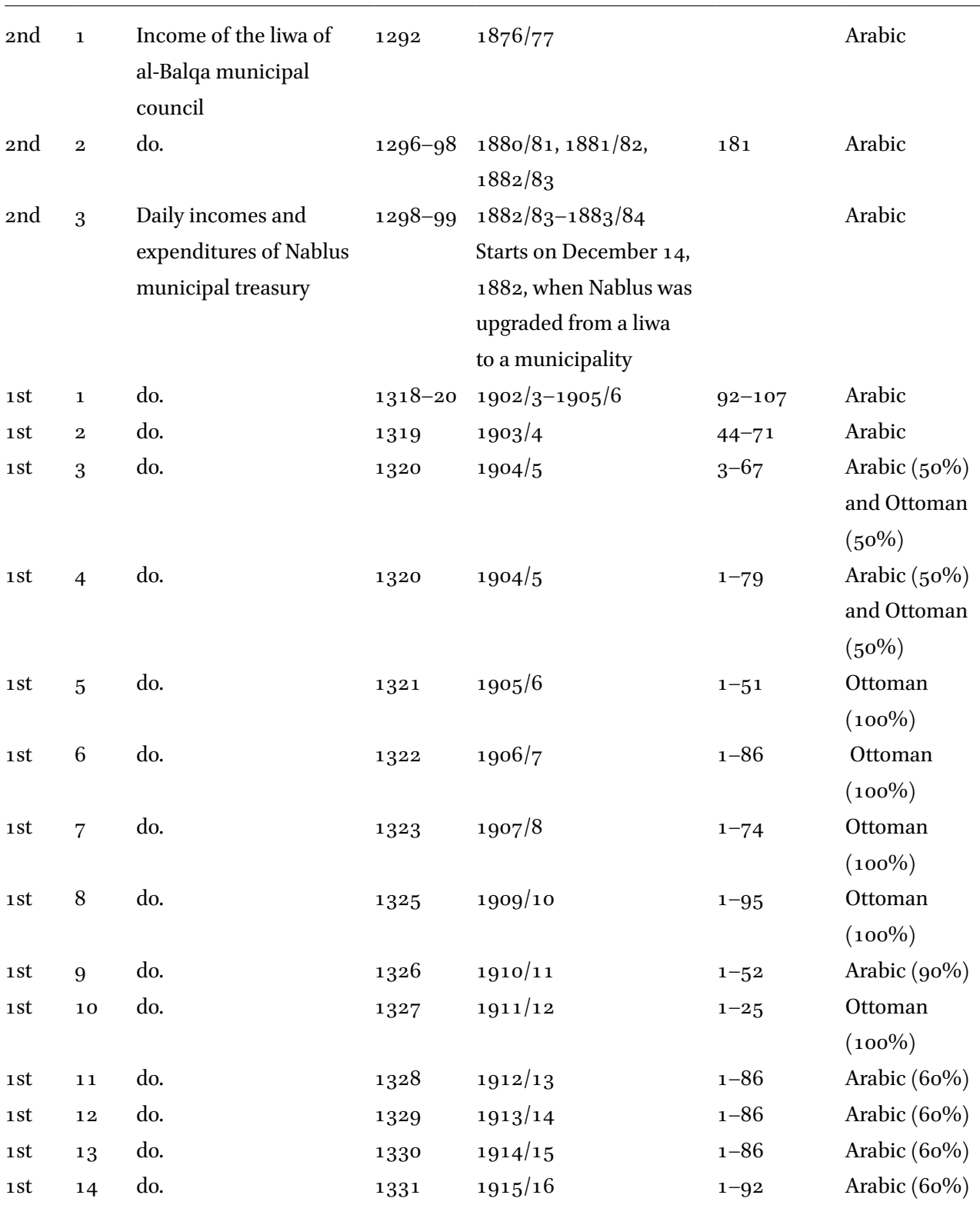




\begin{tabular}{|c|c|c|c|c|c|c|}
\hline \multirow[t]{2}{*}{ Coll. } & \multirow[t]{2}{*}{ Vol. } & \multirow[t]{2}{*}{ Title of daftar } & \multicolumn{2}{|c|}{ Fiscal year } & \multirow[t]{2}{*}{ Pages } & \multirow[t]{2}{*}{ Notes } \\
\hline & & & Maliye & AD (March-February) & & \\
\hline 1st & 15 & do. & 1333 & $1917 / 18$ & $1-168$ & $\begin{array}{l}\text { Ottoman } \\
(100 \%)\end{array}$ \\
\hline 2nd & 4 & $\begin{array}{l}\text { Total (ijmāli) income } \\
\text { of Nablus municipal } \\
\text { treasury }\end{array}$ & $1305^{-8}$ & $1889 / 1990-1893 / 94$ & $1-47$ & \\
\hline 2nd & 6 & do. & $1317-19$ & $1901 / 2-1903 / 4$ & $1-50$ & \\
\hline 2nd & 7 & do. & 1322 & $1906 / 7$ & $1-59$ & \\
\hline 2nd & 8 & do. & 1323 & $1907 / 8$ & $1-54$ & \\
\hline 2nd & 9 & do. & 1324 & $1908 / 9$ & $1-55$ & \\
\hline 2nd & 10 & do. & 1325 & $1909 / 10$ & $1-49$ & \\
\hline 2nd & 11 & do. & 1326 & $1910 / 11$ & $1-53$ & \\
\hline 2nd & 12 & do. & 1327 & $1911 / 12$ & $1-57$ & \\
\hline 2nd & 13 & do. & 1328 & $1912 / 13$ & $1-58$ & \\
\hline 2nd & 14 & do. & 1330 & $1914 / 15$ & $1-74$ & \\
\hline 2nd & 15 & do. & 1331 & $1915 / 16$ & $1-6 o$ & \\
\hline 2nd & 16 & do. & 1332 & $1916 / 17$ & $1-79$ & \\
\hline 2nd & 17 & do. & 1334 & $1918 / 19$ & $90-91$ & \\
\hline
\end{tabular}

The records of these two volumes include income paid to the municipal treasury of fines as well as licenses and services such as taxes due on the Nablus slaughterhouse and other slaughterhouses in the liwa: al-Salt, Jenin, 'Inbta, and elsewhere. The income registers show clearly that, beginning in 1881, the municipality of Nablus started to issue building permits against fixed fees. The amount of these fees reflected the construction activity in the city.

Table 12.2 includes registers entitled "draft register of fixed and anticipated expenditures." Each daftar of this collection is dedicated to one year and is divided into months. Usually the daftar shatib and the ijmäli daftars are dedicated to the fixed monthly salaries of municipal employees. Each page is dedicated to an employee and to the salaries he received throughout the year.

At the end of each month, the registrar, mayor, and members of the municipal council signed and declared that, "According to the above registration of 
TABLE 12.2 Draft daftars (shatib) of expenditure of Nablus municipality (third collection)

\begin{tabular}{|c|c|c|c|c|c|c|}
\hline \multirow[t]{2}{*}{ Coll. } & \multirow[t]{2}{*}{ Vol. } & \multirow[t]{2}{*}{ Title of daftar } & \multicolumn{2}{|l|}{ Fiscal year } & \multirow[t]{2}{*}{ Pages } & \multirow[t]{2}{*}{ Notes } \\
\hline & & & Maliye & AD (March-February) & & \\
\hline 3 rd & 2 & $\begin{array}{l}\text { Draft daftar } \\
\text { (shatib) of } \\
\text { expenditure } \\
\text { of Nablus } \\
\text { municipality }\end{array}$ & $1312-16$ & $1896 / 97-1900 / 1$ & 85 & \\
\hline 2nd & 5 & do. & $1316-21$ & $1900 / 1-1905 / 6$ & & \\
\hline $3^{\text {rd }}$ & 3 & do. & 1319 & $1903 / 4$ & 46 & \\
\hline $3^{\text {rd }}$ & 4 & do. & 1320 & $1904 / 5$ & 73 & Ottoman $(90 \%)$ \\
\hline $3^{\text {rd }}$ & 5 & do. & 1322 & $1906 / 7$ & 100 & \\
\hline $3^{r d}$ & 6 & do. & 1324 & $1908 / 9$ & 88 & \\
\hline $3^{\text {rd }}$ & 7 & do. & 1325 & $1909 / 10$ & 85 & \\
\hline 3 rd & 8 & do. & 1326 & $1910 / 11$ & 88 & \\
\hline 3 rd & 9 & do. & 1327 & $1911 / 12$ & 205 & \\
\hline 3 rd & 10 & do. & 1329 & $1913 / 14$ & 100 & \\
\hline 3 rd & 11 & do. & 1330 & $1914 / 15$ & 106 & \\
\hline $3^{\text {rd }}$ & 12 & do. & 1331 & $1915 / 16$ & 130 & \\
\hline $3^{\text {rd }}$ & 13 & do. & $1332-34$ & $1916 / 17-1917 / 18$ & 160 & \\
\hline 1 st & 15 & do. & 1333 & $1917 / 18$ & $1-173$ & Arabic $(60 \%)$ \\
\hline
\end{tabular}

month , the salaries and expenditures of the treasury of the municipality of Nablus amounted to ; we hereby sign this statement." This statement was repeated at the end of each month.

In table 12.3, I have put together all registers labeled "Minutes, Decisions and Correspondence" (madabit, qararāt and murāsalat). For reasons that remain unclear, the librarians of the municipal archives have divided this collection into two, making them the fourth and fifth collections. Municipal decisions made by the municipal council are numbered serially in each register. On average, each register contains around 400 decisions made over the course of the year. All municipal decisions are written in Arabic. However, these registers contain hundreds of letters, regulations, and orders received from different governmental offices in the wilāya (province) or from Istanbul. Usually, this 
TABLE 12.3 Daftars of minutes, decisions, and correspondence (Madabit, Qararāt and Murāsalat) (fourth and fifth collections)

\begin{tabular}{|c|c|c|c|c|c|c|}
\hline \multirow[t]{2}{*}{ Coll. } & \multirow[t]{2}{*}{ Vol. } & \multirow[t]{2}{*}{ Title of daftar } & \multicolumn{2}{|c|}{ Fiscal year } & \multirow[t]{2}{*}{ Pages } & \multirow[b]{3}{*}{$\begin{array}{l}\text { Arabic } \\
(80 \%)\end{array}$} \\
\hline & & & Maliye & AD (March-February) & & \\
\hline 4th & 1 & $\begin{array}{l}\text { Minutes, } \\
\text { decisions and } \\
\text { correspondence }\end{array}$ & 1292 & $1876 / 77$ & 122 & \\
\hline 4th & 2 & do. & 1319 & $1903 / 4$ & 146 & $\begin{array}{l}\text { Arabic } \\
(80 \%)\end{array}$ \\
\hline 4th & 3 & do. & 1320 & $1904 / 5$ & 202 & \\
\hline 4th & 4. & do. & 1321 & $1905 / 6$ & 144 & \\
\hline 4th & 5 & do. & 1322 & $1906 / 7$ & 147 & \\
\hline 4th & 6 & do. & 1323 & $1907 / 8$ & 219 & \\
\hline 4th & 7 & do. & 1324 & $1908 / 9$ & 312 & \\
\hline 4th & 8 & do. & 1325 & $1909 / 10$ & 320 & \\
\hline $5^{\text {th }}$ & 1 & do. & 1325 & $1909 / 10$ & 284 & \\
\hline 4 th & 9 & do. & 1327 & $1911 / 12$ & 326 & \\
\hline 4th & 10 & do. & 1328 & $1912 / 13$ & 322 & \\
\hline $5^{\text {th }}$ & 2 & do. & 1328 & $1912 / 13$ & 286 & \\
\hline $5^{\text {th }}$ & 3 & do. & 1329 & 1913 & 302 & \\
\hline 4th & 11 & do. & 1330 & $1914 / 15$ & 287 & \\
\hline $5^{\text {th }}$ & 4 & do. & 1330 & $1914 / 15$ & 301 & \\
\hline 4th & 12 & do. & 1332 & $1916 / 17$ & 288 & \\
\hline $5^{\text {th }}$ & 5 & do. & 1333 & $1917 / 1918$ & 291 & \\
\hline
\end{tabular}

material was received in Turkish, and was copied into the registers without translation. The text of municipal decisions fills three to five lines, though in some cases the decision covers an entire page. Almost all correspondence sent from the municipal council to administrative bodies in the wilayya or Istanbul was written in Turkish. An inventory of these collections appears in table 12.3.

In table 12.4, I have compiled all of the registers collected by the Nablus municipal librarians into four collections (sixth, seventh, eighth, and ninth). The archival groupings are once again unclear, but it seems safe to conclude that these divisions are arbitrary. Most of the registers in the sixth collection, as 
they appear in table 12.4, are related to municipal cleaning services. Additional cleaning-related registers are found in the seventh collection. Therefore, I have grouped them in table 12.4. These registers include information about the town's neighborhoods and the fees collected from houses for the cleaning service. The cleaning registers make it clear that Nablus began numbering houses in 1897 in order to improve services and to improve the efficiency of fee collection. The sixth collection includes two registers of the parliamentary elections held in the liwa of Nablus in 1913. These two registers were kept in the municipal archives because the municipal scribes of Nablus were chosen to manage these elections. The reason why the municipal archivists decided to add these two records to this collection remains ambiguous.

It seems that the municipality of Nablus encountered trouble in collecting these fees. Therefore, a new register dedicated to reporting all debts of house owners who did not pay the cleaning fee was created. This register is titled daftar baqāya al-tandhifāt (remnants of debts of cleaning services), and it is kept in the seventh collection.

TABLE 12.4 Daftars (sixth, seventh, eighth and ninth collections)

\begin{tabular}{|c|c|c|c|c|c|}
\hline \multirow[t]{2}{*}{ Coll. } & \multirow[t]{2}{*}{ Vol. } & \multirow[t]{2}{*}{ Title of daftar } & \multicolumn{2}{|l|}{ Fiscal year (Maliye/AD) } & \multirow[t]{2}{*}{ Pages } \\
\hline & & & Starts & Ends & \\
\hline 6th & 1 & $\begin{array}{l}\text { Daftar for the } \\
\text { parliamentary } \\
\text { elections }\end{array}$ & $\begin{array}{l}\text { 10 Kanunusani } 1327 \\
\text { Rumi calendar }(\mathrm{R}) / \\
\text { January } 23,1913\end{array}$ & $\begin{array}{l}16 \text { şubat } 1328 \mathrm{R} / \\
\text { March 1, } 1913\end{array}$ & 67 \\
\hline 6th & 2 & do. & $\begin{array}{l}\text { Kanunuevvel } 1327 \text { R/ } \\
\text { January } 1913\end{array}$ & & 35 \\
\hline 6th & 3 & $\begin{array}{l}\text { Daftar for } \\
\text { cleaning services }\end{array}$ & $\begin{array}{l}1 \text { Mart } 1307-1318 \mathrm{R} / \\
\text { March 13, 1891-1903 }\end{array}$ & & 92 \\
\hline 6th & 4 & do. & $\begin{array}{l}1 \text { Mart } 1310 \mathrm{R} / \text { March } \\
13,1894\end{array}$ & & 160 \\
\hline 6th & 6 & do. & $\begin{array}{l}1 \text { Mart } 1313 \mathrm{R} / \\
\text { March 13, } 1897\end{array}$ & $\begin{array}{l}\text { Teşrinsani } 1315 \mathrm{R} / \\
\text { November 13, } 1897\end{array}$ & 166 \\
\hline $7^{\text {th }}$ & 1 & $\begin{array}{l}\text { Daftar of unpaid } \\
\text { debts for } \\
\text { cleaning services }\end{array}$ & $\begin{array}{l}1 \text { Mart 1307-27 şubat } \\
1318 \mathrm{R} / \text { March 13, } \\
\text { 1891-March 12, } 1903\end{array}$ & & 182 \\
\hline
\end{tabular}


Coll. Vol. Title of daftar Fiscal year (Maliye/AD)

Pages

Starts Ends

\begin{tabular}{|c|c|c|c|c|c|}
\hline $7^{\text {th }}$ & 2 & $\begin{array}{l}\text { Daftar of money } \\
\text { collected } \\
\text { (taḥ̣ịlāt) for } \\
\text { cleaning services }\end{array}$ & $\begin{array}{l}1 \text { Mart 1310 R/ } \\
\text { March 13, } 1894\end{array}$ & $\begin{array}{l}27 \text { şubat } 1310 \mathrm{R} / \\
\text { March 11, } 1895\end{array}$ & 160 \\
\hline $7^{\text {th }}$ & 3 & do. & $\begin{array}{l}1 \text { Mart 1313 R/ } \\
\text { March 13, } 1897\end{array}$ & $\begin{array}{l}27 \text { şubat } 1315 \mathrm{R} / \\
\text { March 1, } 1898\end{array}$ & 168 \\
\hline $7^{\text {th }}$ & 4 & do. & $\begin{array}{l}1 \text { Mart 1317 R/ } \\
\text { March 14, } 1901\end{array}$ & $\begin{array}{l}27 \text { şubat } 1317 \mathrm{R} / \\
\text { March 12, } 1902\end{array}$ & $15^{2}$ \\
\hline 8th & 1 & $\begin{array}{l}\text { Daftar of orders } \\
\text { (Ar. awāmir, Ott. } \\
\text { Turk: evāmir) of } \\
\text { the wilāya }\end{array}$ & $\begin{array}{l}1 \text { Mart 1316 R/ } \\
\text { March 14, } 1900\end{array}$ & $\begin{array}{l}\text { şubat } 1318 \mathrm{R} / \\
\text { March } 1903\end{array}$ & 82 \\
\hline 9th & 1 & $\begin{array}{l}\text { Daftar of } \\
\text { monthly subsidy } \\
\text { (payment for the } \\
\text { needy) of liwa } \\
\text { al-Balqa }\end{array}$ & $\begin{array}{l}1 \text { Mart } 1293 \mathrm{R} / \\
\text { March 13, } 1877\end{array}$ & $\begin{array}{l}27 \text { şubat } 1294 \text { R/ } \\
\text { March 11, } 1879\end{array}$ & 69 \\
\hline 9th & 2 & $\begin{array}{l}\text { Daftar of } \\
\text { population } \\
\text { census }\end{array}$ & $1299 \mathrm{R} / 1883$ & $1324 \mathrm{R} / 1908$ & 33 \\
\hline 9th & 3 & $\begin{array}{l}\text { Daftar of } \\
\text { incomes of } \\
\text { contract stamps }\end{array}$ & $1303 \mathrm{R} / 1887$ & $1324 \mathrm{R} / 1909$ & 41 \\
\hline 9th & 4 & $\begin{array}{l}\text { Daftar of } \\
\text { gazhane (Ar. } \\
\text { kazkhanah) }\end{array}$ & $1304 \mathrm{R} / 1888$ & & 44 \\
\hline $9^{\text {th }}$ & 5 & $\begin{array}{l}\text { Daftar records } \\
\text { of incoming } \\
\text { (received) letters }\end{array}$ & $1321 \mathrm{R} / 1905$ & $1324 \mathrm{R} / 1909$ & 46 \\
\hline 9th & 6 & $\begin{array}{l}\text { Daftar of } \\
\text { minutes and } \\
\text { decisions of } \\
\text { different offices }\end{array}$ & $1331 \mathrm{R} / 1915$ & & 47 \\
\hline
\end{tabular}




\begin{tabular}{llllll} 
Coll. & Vol. & Title of daftar & \multicolumn{2}{c}{ Fiscal year (Maliye/AD) } & Pages \\
\cline { 3 - 4 } & & Starts & Ends & \\
\hline 3 rd & 1 & $\begin{array}{l}\text { Daftar of } \\
\text { monthly salaries } \\
\text { of municipal } \\
\text { employees } \\
\text { 3rd }\end{array}$ & $1316-21$ & $1900 / 1-1905 / 6$ & 68 \\
& $\begin{array}{l}\text { Reports of the } \\
\text { municipality } \\
\text { inspector }\end{array}$ & 1334 & 1918 & 130 \\
& & & \\
\end{tabular}

Compared to the wealth of municipal archives from Nablus, local sources from Ottoman Haifa are very rare. The town was largely destroyed during the Nakba - 95 percent of Haifa's Palestinians were expelled from their homes and the Ottoman city was mostly cleansed. However, a photocopy of the sijill of the Haifa shari'a court from the 1870 s is kept in the library of Haifa University, ${ }^{11}$ and the municipal records from the Mandate period are well organized. ${ }^{12}$ These two sources shed some light on the activities of Haifa's Ottoman municipality. Unfortunately, there is a total lack of municipal documents or other governmental documents from Ottoman Haifa.

Similarly, the municipal archives of Ottoman Nazareth have completely disappeared. No Ottoman municipal records or files can be found. The municipal archives of Nazareth from the Mandate period are poor and many records are missing. ${ }^{13}$ However, sharia court records from the Ottoman period were recently discovered and are now kept at the Israel State Archives in Western Jerusalem. Missionary institutions and churches have kept registrations and documents from the late Ottoman period, which may reveal details about

11 University of Haifa Library, Micr. 911. The microfilmed collection contains seventeen rolls and goes from 1872 to 1948 . The Ottoman collection contains twelve volumes from 1872 until 1917. However, a new collection of the sijillät of Haifa was recently discovered in Nablus Municipal Archives. This collection contains seven volumes and covers the years 1864-72.

12 The historical municipal archives of Haifa are kept in the municipal archives offices in the German colony. They are well organized and the large amounts of files from the Mandate period are open to researchers. Unfortunately, no files from the late Ottoman period exist.

13 Unfortunately, the municipality of Nazareth does not possess historical archives of the Ottoman and Mandate periods. 
the municipal activities during the Ottoman period. ${ }^{14}$ Additionally, a local Protestant priest, As'ad Mansur, left behind a source which is vital to the reconstruction of Ottoman Nazareth history. He wrote a book during the last years of Ottoman rule and published it in 1924. In it, he recorded many events from the late Ottoman period and documented important information about the town's municipal council. ${ }^{15}$ In 1908, when Palestinian local newspapers started to appear, Mansur's work became an important source of information about the activities of municipal councils in Palestine.

\section{Public Urban Services before the Municipalities}

Until the 1840 , there was no tangible Western presence in Palestine apart from some consuls and vice-consuls in the coastal towns and Jerusalem. In inland towns such as Nablus, Western influence was hardly felt before the end of Ottoman rule. However, in spite of the absence of Europeans, there were definite changes in the city's socioeconomic and political structures post-Tanzimat. ${ }^{16}$ Nablus offers a near ideal case study if we wish to trace how municipal councils were introduced, and then functioned, far from European intervention or influence.

Some municipalities in Palestine were established before the 1871 amendment of the Vilayets Law, which referred to the municipality for the first time. The law was a product of the central government's strategy to use municipalities to reinforce its policies. Indeed, while members of the council were elected, the mayor was nominated by the mutessarif, who was responsible to the province's wälì.

Consultative council documents from Nablus show that waste was collected daily and the councilors noted that "cleaning the town is a precondition for maintaining public health,"17 suggesting that public services existed in the town a full two decades before the official municipality was established there. During his visit to Nablus in 1863, Henry B. Tristram, an English clergyman and

14 Mahmoud Yazbak, "Nablus, Nazareth and Haifa: Three Ottoman Towns in an Age of Transformation, 1840-1914," in Essays on Ottoman Civilization, Proceedings of the XIIth Congress of Ciepo (Prague: Academy of Sciences of the Czech Republic, Oriental Institute, 1998).

15 Mansur, Tarikh al-Nasira, 158, 168, 176.

16 Doumani, Rediscovering Palestine, 9, 23, 68, 73-74; Abu-Manneh, "Islamic Roots."

17 Records of majlis al-shūrā of Nablus, vol. 1, p. 55 (these manuscripts are kept in the library of al-Najah University of Nablus). 
scholar, observed that because of efforts made by the consultative council as early as the 1840 , the streets of Nablus were cleaner than those of Jerusalem at the time. ${ }^{18}$

In 1855, a similar effort was made by the local administration in Haifa, two decades before the municipality was established. Mary Rogers, the sister of the British vice-consul in Haifa, wrote that her brother urged the local Ottoman administration "to cleanse the guttered streets of Haifa ... and advised the removal of the dust heaps by the sea shore ... the appeal was favorably heard, the work actually commenced immediately, and Haifa underwent sweeping and scraping ... and the dust heaps were ... shoveled into the sea."19

Similar actions were taken by nearly every local society and administration years before municipalities were established. ${ }^{20}$ Granted, services such as these were very limited and often not well-regulated. After the establishment of municipalities, urban services expanded and were regulated by laws. ${ }^{21}$

\section{Establishing Municipalities}

The first municipality in Palestine was established in 1863 in Jerusalem. ${ }^{22}$ Nablus followed in 1868, while other towns such as Nazareth and Haifa were established as municipalities only after the 1871 amendment. The establishment of a municipality in Nablus occurred earlier than in other towns, and was likely related to the upgrading of the administrative status of the town: in 1868, it became the center of a mutasarifiyya, which formed part of the vilayet of Syria instead of the sanjak of Jerusalem. The city's population was more than 20,000, and a consultative council (majlis al-shürā), the forerunner of the administrative council (majlis al-idāra), was in place there by the early 1840 .

The earliest mention we find of a city council functioning in Haifa is in a sijill entry from $\mathrm{AH} 1290$ (1873), which contains the testimony of a municipal council member before the shari'a court. ${ }^{23}$ The first head of municipality we

18 Henry B. Tristram, The Land of Israel: A Journal of Travels in Palestine (London: Society for Promoting Christian Knowledge, 1882), 106.

19 Mary E. Rogers, Domestic Life in Palestine (1862; repr., London: Kegan Paul, 1989), 143.

20 Many examples are listed in Yazbak, "Municipality of a Muslim Town," 341-42.

21 A long list and thorough discussion of the new municipal urban services (security, supervision of markets, sanitation, lighting, town planning, etc.) are discussed in Yazbak, "Municipality of a Muslim Town," 348-59.

Bahjat Sabri, "Liw' al-Quds Athna al-Hukm al-'Uthmani, 1840-1873" [The Jerusalem liwa during Ottoman rule, 1840-1873] (PhD diss., 'Ain Shams University, 1973), 69.

23 Sijill of Haifa, AH 8 Muharram $1290\left(1873^{-74}\right)$. 
hear of by name is Mustafa Bey al-Salah, in the salname (official annual) of $1298(1881 / 82)$, though it is not clear whether he was the first council member. Mustafa Bey al-Salah was a Muslim and the son of 'Abdallah Bey al-Salah, who had been a prominent figure in the local administration for many years. ${ }^{24}$ Members of the al-Salah family served various administrative positions and were considered among the richest families in the city and Haifa's qada' (subdistrict). Until the end of Ottoman rule, only Muslim mayors headed Haifa's municipal council. The salname of Syria of $1880-81$ reported that four Christians and two Muslims sat on the municipal council, ${ }^{25}$ and no more than six members ever sat on the council until the end of Ottoman rule. It seems that the religious affiliation of the council's members reflected the demographic structure of the city. A similar division can be detected in other Palestinian municipal councils. Usually, the municipal council consisted of six to twelve members according to the size of the population. ${ }^{26}$

The municipality of Nazareth was founded in 1875 , and its first mayor was Tannus Qa'war, a member of the Greek Orthodox community. He served in this position consecutively for ten years. Before his nomination as mayor of Nazareth, he headed his community for many years and served in various administrative positions such as head of the Nizāmi (civil) court in Nazareth and a member of the general council of the vilayet of Beirut. ${ }^{27}$ From 1875 to the end of the Ottoman period, eleven different mayors served Nazareth, some of them serving more than one term. All of the mayors were local men and were affiliated with four or five of the town's elite families. Unlike in Haifa and Nablus, where mayors were only Muslim, both Muslim and Christian mayors served in Nazareth. ${ }^{28}$ Nazareth's Christian majority is a likely explanation for these nominations. The religious affiliation of the municipal council members also reflects the demographic structure of the town's population. The municipal council of Nazareth consisted of seven elected members; two were Muslims and the rest were Christians. The Christian members represented the

24 Yazbak, Haifa in the Late Ottoman Period, 24.

25 Ibid., 77; Salname of Syria, 1298 (1880-81), 198.

26 Omar Bey Salih al-Barghuti, "Local Self-Government: Past and Present," The Annals of the American Academy of Political and Social Sciences 164 (1932): 36; Young Georges, "Municipalités provinciales," in Corps de droit ottoman recueil des codes, lois, règlements, ordonnances et actes les plus importants du droit intérieur, et d'études sur le droit coutumier de l'Empire ottoman (Oxford: Clarendon Press, 1905-6), 69-84.

27 Mansur, Tarikh al-Nasira, 97, 100, 302; Salname of Syria, 1298, 199; 1299, 221; 1300, 215 (Abbas Fahum was mayor for a short period); 1301, 218 (Tanus Qa'war was renominated); 1302, 171.

28 Frederic John Scrimgeour, Nazareth of Today (Edinburgh: William Green, 1913), 98. 
three Christian denominations living in Nazareth: Greek Orthodox, Roman Catholics, and Maronites. ${ }^{29}$

According to the 13 salnames of $1880-1908$, six members consistently sat on Haifa's municipal council. Our sources provide data on seventy-eight members. During the period under investigation, thirty-one people belonging to twenty different families were elected to the municipal council, some serving more than one two-year term. Eleven of the families were Muslim, among whom turnover appeared to be more rapid than among the remaining nine Christian families. Muslim families sent twenty-nine members to the council and Christian families sent forty-nine. Muslim members served an average of two years, while Christian members served much longer terms and often more than one. While the Christian community rallied around their representatives, who represented most of the Christian sects in the city, it would seem that competition among the A'yan resulted in a quicker turnover of the Muslim representatives. That fact that more Christians served on Haifa's municipal council than Muslims was due to the presence of three Christian denominations in Haifa, and to the entire Christian franchise joining forces to back a limited number of families. The Muslim elite representatives lost votes due to their disunity and intracommunal competition. In most years, Haifa's municipal council comprised more Christian members than Muslim. The Christians managed to maintain both a relative and an absolute majority in the council though they remained outnumbered by the Muslims. ${ }^{30}$ The salnames also reveal that Haifa's municipal council represented only two of the three existing communities - Jews did not sit on the council despite a stipulation in the legislation that members of all the asnaf (communities and strata) could be elected to it. Although Ottoman Jews were allowed to vote, they were not large enough in number to gain representation on the council.

As a body of local government, the municipal council promoted the inclusion of non-Muslims in public life and official positions. The composition of Haifa's municipal council proves that the stipulation made by the Vilayets Law, that the administrative council of the qada' should be of "Muslim and non-Muslim"31 members, was fully adopted by the local government in its constituency even though the Muslims lost out as a result. However, officials serving in the administration on behalf of the central government (the mutasarrif and qaimaqam) would not allow the appointment of a Christian mayor

\footnotetext{
29 Mansur, Tarikh al-Nasira, 302.

30 For a thorough discussion of the Haifa municipal council's members, see Yazbak, Haifa in the Late Ottoman Period, $81-83$.

31 Ibid., 82, n. 263.
} 
in Haifa, even when the majority in the council demanded as much, because the Muslims remained the majority of the population. In Nazareth, on the other hand, with its predominantly Christian population, the government did appoint a Christian mayor from time to time.

\section{Municipal Elections and a Shift in Societal Stratification}

Before the Tanzimat and the establishment of new local governmental offices such as administrative and municipal councils, a deep social change took place in Palestine. By the mid-nineteenth century, all of Palestine was subject to the administrative changes that the Ottomans imposed throughout the empire. A second decisive factor for the transformation of Palestine during the second half of the nineteenth century was the economic and political infiltration of the country by the West.

The increased monetization of the economy by the mid-nineteenth century opened the way for urban merchants to become large landowners, causing a shift in societal stratification. However, this economic source of power alone was not enough for the new upstart merchants to arrive at positions of leadership and authority as they lacked an adequate stage on which they could demonstrate their political interests and power. These positions could be accessed through local administrative institutions created by the Tanzimat, of which the municipal council was a prime example.

Nouveau riche Muslim and Christian families, previously unknown, succeeded economically and competed with established families. ${ }^{32}$ Tracing the members of the municipal councils of Haifa, Nablus, and Nazareth, we find that besides members of the old established elite, individuals from upcoming families had made their way to top positions in administrative institutions in general and municipalities in particular. New faces in fact worked their way to the top of local societies. In Haifa and Nazareth, where large non-Muslim groups lived, the changing societal stratification led to open competition for administrative posts. In Nablus, which had only a small non-Muslim minority, such competition did not occur.

According to the Municipalities Law, only those in a town who could show they had economic resources were eligible to take part in the municipal elections. Eligible candidates were males aged twenty-five or older who had paid

32 For a thorough discussion of these families, see Yazbak, Haifa in the Late Ottoman Period, chap. 4, 112-58; Yazbak, "Municipality of a Muslim Town," 342-44; Yazbak, "Europe, Cotton and the Emergence." 
an annual property tax of at least 50 qurush. ${ }^{33}$ Candidates for the municipal council had to be of upright character, and were required to possess property and land with a yearly income of at least 5,00o qurush, and pay property tax of at least 100 qurush. ${ }^{34}$ Those who met these criteria usually belonged to the economic and social elite. In Nablus, for example, the municipal archival sources show that out of a total population of 30,000 (with 6,261 males over 25 years old), ${ }^{35}$ only 304 people satisfied these conditions; of these, only 114 were eligible as candidates. ${ }^{36} \mathrm{~A}$ similar picture emerged during the municipal elections in Jerusalem at the end of the nineteenth century. In these elections, fewer than 700 Muslims and 300 Christians were eligible out of a total population of around $20,000 .^{37}$

The property tax (wirko) department put up lists with the names of all those eligible to vote and run for office in public places in the town. ${ }^{38}$ Headed by the mayor, an election committee composed of two respected representatives of each quarter was chosen by the mukhtars and imams of the neighborhood to supervise and run the ballot. Since elections were held once every four years, voters elected double the number of members required for the municipal council: half of them served in the first session (two years) and the others in the second. ${ }^{39}$ The election committee not only supervised the voting procedure but also had the power to choose which successful candidates would serve in the first session of the municipal council. This resulted in various coalitions in the town increasing pressure on the mukhtars and imams to select their members and representatives.

In practice, the committee members reflected the balance of power in the town. Even though membership of the municipal council, like other local elected governmental institutions, was unremunerated, it was seen as recognition of prominent social status within society (na'ilin al-qadr lahum wa-l-itibār

33 Mahmoud Yazbak, "Elections in Late Ottoman Palestine: Early Exercises in Political Representation," in Late Ottoman Palestine: The Period of Young Turk Rule, eds. Yuval BenBassat and Eyal Ginio (London: I. B. Tauris, 2011), 51, n. 3. MAN, d. 4, b. 3, c(ase) no. 64; al-Dustur, trans. Nawfal Nawfal, vols. (Beirut, AH 1301), vol. 2, 410, 433; Haim Gerber, Ottoman Rule in Jerusalem, 1890-1914 (Berlin: Schwarz, 1985), 116.

35 MAN, d. 6, b. 1, p. 14.

36 Ihsan al-Nimr, Tarikh Jabal Nablus wa al-Balqa [History of Nablus and Balqa], 4 vols. (Nablus, n.d.), vol. 3, 26.

37 Yazbak, "Elections in Late Ottoman Palestine," 36, n. 5.

38 MAN, d. 4, b.1, no. 364. misc., 9 Nisan 1330 M/June 22, 1914.

39 MAN, d. 6, b. 2, misc., 9 Nisan 1330 M/June 22, 1914; Yazbak, "Elections in Late Ottoman Palestine," 55 . 
bayn aqranahum $).^{40}$ Being elected to the municipal council opened doors to other governmental institutions in the locality. This was because members of local governmental institutions such as the Agricultural Bank, the court of first instance (mahkamat al-bidaya), the orphanage treasury, the education board, the communications board, and others, were chosen from among council members. ${ }^{41}$ Besides respect and prominence, membership in local governmental institutions gave the municipal councilor a genuine opportunity to influence the council's decisions and protect his interests and those of his supporters and coalition. Prominent social figures competed fiercely for these posts, which led to the formation of family coalitions, or, as they were called in Nablus, jam 'iyyat, "family leagues" as a basis for forming "election lists."42

The jamiyyat were created to promote members of the families that belonged to them. In other words, they were pressure groups that worked to ensure the election of their own candidates to the administrative institutions in town. Crucial to the jamiyyat was that their founders did not belong to the old ruling elite. Though the old elite had lost power to an extent, it continued to use its legacy as a means of integrating into the new administrative institutions. The rising elite, on the other hand, could have no chance of winning municipal elections without newly formed coalitions. ${ }^{43}$ These were coalitions of prominent figures of society and families who cooperated to win administrative posts, thereby to bid more easily for government iltizām (tax farming).

Although they involved only the wealthy elite, the municipal elections became an important instrument through which participants affirmed their social position. Together with the changing material power bases that made wealth the prominent factor in helping members rise through social structures, elections opened the way for others, especially merchants, to participate in local administration. Traditional social forces, the old ruling elite, and the 'ulama', who held their posts almost always through inheritance, found themselves dislodged unless they possessed the required means of accumulating wealth (large tracts of land, commerce, and the iltizām). Municipal elections paved the way for the nouveaux riches to make their way into administrative posts and to influence political developments in the town.

\footnotetext{
40 Al-Najah University Archives and Manuscripts, Nablus, Records of Majlis al-Shura of Nablus, vol. 1, case no. 80 .

41 MAN, d. 5, b. 2, no. 169; d. 4. b. 1, no. 406; d. 4, b. 7, no. 126.

42 Al-Nimr, Tarikh Jabal Nablus, vol. 3, 56-65; Muhammad 'Izzat Darwazih, Mudhakarrat wa Tasjilat [Memories and remembrances], 2 vols. (Amman, 1984), vol. 1, 177-80.

43 For a thorough discussion of the jam iyyat see Yazbak, "Municipality of a Muslim Town," $344-48$.
} 
In Haifa and Nazareth, there was no societal factionalism. As a result, coalitions such as the jam iyyat could not develop. Intercommunal strife and continuous development in both towns contributed to this state of affairs. Only toward the end of Ottoman period in Haifa do we find anything vaguely resembling the family coalitions of the towns in central Palestine. By then, obtaining positions in the administration had become of vital importance both for the upstarts as a way of integrating into the elite as for the established families in order to hold onto their legacies. This led to a blurring of the borders between the town's three elite groups. The 'ulama' families were no longer content with positions solely in the 'ilmiyya institutions. The tujjär (large-scale merchants) looked for positions in the new administrative offices, competing with the families of the old elite. However, these attempts remained secondary to the main arena of competition for power in Haifa and Nazareth: established prominent Muslim families vying for authority against new upstart Christian families.

\section{From Nablus to Jerusalem and Back}

The municipal council (Ar. majlis baladiyya; Ott. Turk. meclis-i belediye) of Nablus came into existence in 1868, shortly after the establishment of the municipality of Jerusalem. Other municipalities in Ottoman Palestine such as Haifa and Nazareth were established only after the publication of the Ottoman municipality law in 1877. However, municipal archival registers in Palestine are found only in Jerusalem and Nablus. Researchers have not yet succeeded in discovering other municipal archives from Ottoman Palestine. Comparing our findings from the Nablus municipal archives as presented in tables 12.1-4 with those of Jerusalem (discussed by Avcı, Lemire and Naïli), ${ }^{44}$ it becomes evident that these archives provide a great wealth of information not only about the administrative evolution of the town, but also about social, economic, cultural, and political issues in late Ottoman cities. Vincent Lemire and the research team of the Open Jerusalem project are now bringing to life the municipal archives of Jerusalem. In light of this development, and even after the publication of my "The Municipality of a Muslim Town: Nablus, 1868-1914" in 1999, researchers have not chosen to consult the municipal archives of Nablus. ${ }^{45}$ Comparing findings from the municipal archives of Nablus and Jerusalem

\footnotetext{
44 Yasemin Avcı, Vincent Lemire, and Falestin Naïli, "Publishing Jerusalem's Ottoman Archives (1892-1917): A Turning Point for the City's Historiography," Jerusalem Quarterly, no. 60 (2015).

45 Yazbak, "Municipality of a Muslim Town," 339-6o.
} 
could develop our understanding of how much autonomy existed for municipal action against centralizing policies.

The Nablus notebooks from 1876 have been preserved, while the notebooks from Jerusalem exist from 1892 onwards. It is difficult to explain why municipal registers from previous years have disappeared. Comparing the notes of Avcr, Lemire and Naïli about the municipal registers of Ottoman Jerusalem with those of Nablus, we observe that the scribes in Nablus wrote their notes in a clearer hand, and contents were easier to read. As in Jerusalem, notebooks (qararāt) were used in Nablus to report the council's decisions and activities. The qararāt notebooks included a large roster of building reports. Deep reading and analysis of these documents enables researchers to follow building patterns and the changing landscape of the city. As in Jerusalem, Nablus daftars mix Arabic and Ottoman languages in continuous alternation. We could not find an explanation for this, given that all Nablus municipal council members were locals who had mastered Arabic.

The municipal archives of late Ottoman Nablus and Jerusalem reveal aspects of the cities' history and the scattered information about the municipalities of Haifa and Nazareth allows researchers to look into neglected aspects of the cities, especially urban activities. In this respect, municipal archives also reveal the extent to which the city's population cooperated with the new administration and showed a willingness to accept new regulations. Regulations regarding buildings permissions are a fine illustration of this. The municipal archives of Jerusalem and Nablus demonstrate that the population of the two cities cooperated with and paid fees for building permissions. The municipalities actively applied construction regulations and infrastructure planning measures in new neighborhoods such as the Shwitra neighborhood in Nablus, Jaffa road in Haifa, and outside the walls of Jerusalem. 